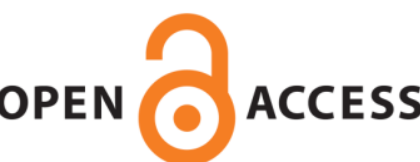

UWS Academic Portal

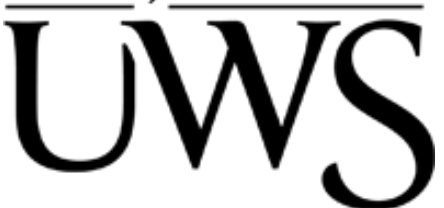

\title{
Benefits of enrichment on the behaviour of ornamental fishes during commercial transport
}

Vanderzwalmen, Myriam; Carey, Peter; Snellgrove, Donna; Sloman, Katherine A.

Published in:

Aquaculture

DOI:

10.1016/j.aquaculture.2020.735360

Published: 15/09/2020

Document Version

Peer reviewed version

Link to publication on the UWS Academic Portal

Citation for published version (APA):

Vanderzwalmen, M., Carey, P., Snellgrove, D., \& Sloman, K. A. (2020). Benefits of enrichment on the behaviour of ornamental fishes during commercial transport. Aquaculture, 526, [735360].

https://doi.org/10.1016/j.aquaculture.2020.735360

\section{General rights}

Copyright and moral rights for the publications made accessible in the UWS Academic Portal are retained by the authors and/or other copyright owners and it is a condition of accessing publications that users recognise and abide by the legal requirements associated with these rights.

Take down policy

If you believe that this document breaches copyright please contact pure@uws.ac.uk providing details, and we will remove access to the work immediately and investigate your claim. 


\section{Benefits of enrichment on the}

\section{2 behaviour of ornamental fishes during}

\section{3 commercial transport.}

4

5 Myriam Vanderzwalmen ${ }^{\mathrm{a}}$, Peter Carey ${ }^{\mathrm{b}}$, Donna Snellgrove ${ }^{\mathrm{c}}$ and Katherine A. Sloman ${ }^{\mathrm{a}}$

6 a School of Health and Life Sciences, University of the West of Scotland, Paisley, PA1 2BE,

$7 \quad \mathrm{UK}$

8 bPets at Home, Handforth, Cheshire, UK

$9{ }^{c}$ WALTHAM Petcare Science Institute, Waltham-on-the-Wolds, LE14 4RT, Leicestershire,

$10 \quad \mathrm{UK}$

11 correspondence

12 Myriam Vanderzwalmen, School of Health and Life Sciences, University of the West of

13 Scotland, Paisley PA1 2BE, UK. Tel: 00441418483371 Email:

14 myriam.vanderzwalmen@uws.ac.uk 


\section{Highlights}

- The effect of enrichment on fish behaviour during commercial transport was studied.

- Enrichment during transport reduced erratic swimming on arrival and post-transport.

- Enrichment during transport reduced chasing behaviours post-transport.

- Enrichment during transport reduced stress-related behaviours during recovery.

- Enrichment could reduce transport-stress for millions of ornamental fishes. 


\section{Abstract}

16 Environmental enrichment is known to reduce stereotypical behaviours in a wide range of

17 captive animals, providing clear welfare benefits in many species. However, one of the most

18 significant stressors faced by captive animals is live transport but whether enrichment can

19 alleviate transport stress is unknown. Using behavioural measures as indicators of fish

20 welfare, we investigated whether the addition of environmental enrichment can improve the

21 welfare of ornamental fish during commercial transport. Pairs of bags containing variatus platy (Xiphophorus variatus) were transported by road with or without enrichment (plastic loops) from a UK wholesaler to one of two stores, the first and the last store on a delivery

24 route. Transport time to the first store was short $(<4 \mathrm{~h})$ and longer $(>6 \mathrm{~h})$ to the second. Fish

25 behaviour and incidences of mortality, disease and injury were recorded immediately

26 following transport and during a four-week recovery period. Immediately post-transport,

27 significantly fewer occurrences of erratic swimming were observed in the enriched group compared to the control group, and lower levels of chasing were recorded in the enriched

29 group during recovery. This study is the first to demonstrate the behavioural benefits of

30 enrichment during live transport of fishes under commercial conditions.

31 Keywords: environmental enrichment, ornamental fishes, stress, transport, welfare. 


\section{Introduction}

Enrichment is often added to the housing of captive animals with the aim of improving their welfare (Carlstead and Shepherdson, 2000; Young, 2003). Enrichment is defined as an increase in environmental complexity that aims to reduce maladaptive and aberrant traits in animals (Näslund and Johnsson, 2016). Structural complexity can be added to provide enclosures mimicking the natural environment (Young, 2003), social complexity can enrich an animal's environment through housing with conspecifics or different species (Bloomsmith and Lambeth, 2000; De Rouck et al. 2005; Sloman et al. 2011) and dietary complexity can include food flavour, texture and shape variation (Skibiel et al. 2007; Rozek and Millam, 2011). Reported benefits of enrichment include improved feeding, lowered metabolic rates, positive behavioural changes and improved cognitive performance (Millidine et al. 2006; Rozek and Millam, 2011; Mileva and Bielajew, 2015; Grimberg-Henrici et al. 2016 ). While diversity in the environmental requirements of animals means that the response to enrichment is often species (Costa et al. 2018), life-stage (Ullah et al. 2017) and contextspecific (Wood, 1998), positive effects of enrichment have been documented across a wide range of animals (Wood, 1998; Belz et al. 2003; Baumans et al. 2005; Milgram et al. 2005; De Rouck et al. 2005; DeVries et al. 2007; Ellis, 2009; Cornale et al. 2015; Sullivan et al. 2016)

For many captive animals, one of the major challenges to their welfare is the stress they encounter during live transport (Grandin, 1997; Harmon, 2009; Nomura et al. 2009). Given the benefits of enriched housing, it is possible that enriched transport could provide similar effects. Studies on the benefits of enrichment during transport are restricted to pigs and monkeys (Peeters and Geers, 2006; Fernström et al. 2008; Roldan-Santiago et al. 2015); 
while these studies have found mixed results there is some evidence to suggest benefits of enrichment during transport. For example, providing maize-filled balls to pigs during

transport and lairage resulted in lower plasma lactate concentrations and reduced incidents of

60 shoulder injuries compared to control pigs (N.B. significance was taken as $p<0.1$ ) (Peeters and Geers, 2006). Addition of straw bedding during piglet transport attenuated physiological effects of transport stress (Roldan-Santiago et al. 2015). Social enrichment during simulated transport of cynomolgus monkeys (Macaca fascicularis) reduced stress-associated behaviours (Fernström et al. 2008).

Ornamental fishes within the aquarium trade experience long transports (from a few hours to $>48 \mathrm{~h}$ ) by road and aeroplanes. Stressors associated with transport include handling, crowding and degrading water quality. The aim of the present study was to assess potential benefits of adding structural enrichment during commercial transport of ornamental fishes.

We hypothesised that structural enrichment would provide shelter and disrupt physical contact between fish during transport, leading to reduced stress-related behaviours posttransport. The behaviour of variatus platy (Xiphophorus variatus), transported by road with or without enrichment (loops of floating plastic), was examined immediately post-transport and during four weeks of recovery at a retailer.

\section{Methods}

\subsection{Study animals and data collection}

Variatus platy (random mix of males and females) were transported from a UK wholesaler to two retail stores (journey range: $8.5-10.7 \mathrm{~km}$ ). Transportation time to the first store was $\sim 2 \mathrm{~h} 30 \mathrm{~min}$ (short transport) and $7 \mathrm{~h}$ to the second store (long transport). At the 
wholesaler, platys ( $\sim 3.5 \mathrm{~cm}$ in length) were netted and placed into polythene bags containing tank water (5-10 fish in $11,25.5 \times 35 \mathrm{~cm}$ bags, bags were $\sim 25 \%$ filled). The air at the top of the bags was replaced with pure oxygen and the bags air-tight sealed and placed into an insulated packing box along with a variable number of other bags. The number of fishes in

shipments could be identified. At store 1 (short transport) all the fish from one bag were sold prior to the end of the data collection, so this pair was excluded from statistical analysis.

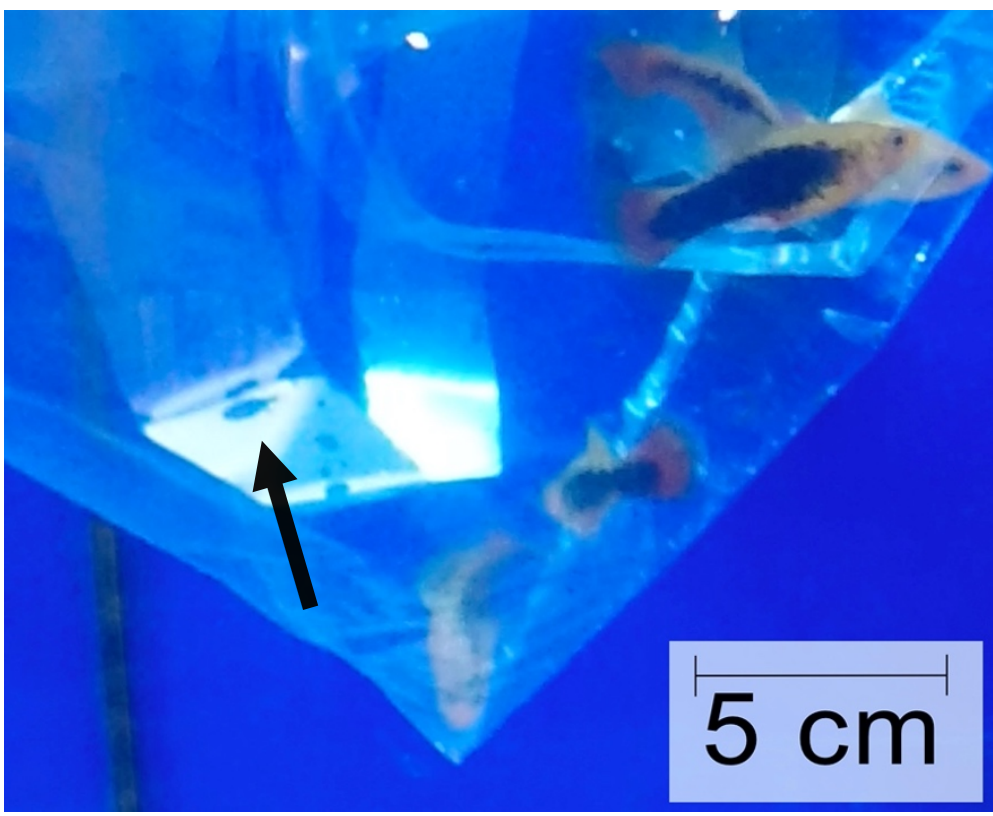

95 Figure 1: Enrichment. Example photograph of plastic loop used as enrichment during 96 transport (indicated by the arrow). 
On arrival at the retail stores, bags were floated in separate recovery tanks for $30 \mathrm{~min}$,

99 during which time fish were recorded using a GoPro hero 5 camera set to 1080P (progressive

100 scan) $120 \mathrm{fps}$ (frames per seconds) with a wide angle. Cameras were mounted on a monopod

101 attached to the outside of the tank. The bags were then opened to allow for slow mixing of

102 the water and after a further 30 min the fish were released into the tank. Staff at the retail

103 stores were unaware of the treatments or study aims to avoid any bias in daily husbandry

104 practices. Preliminary trials found that water parameters in the bags on arrival at the stores were $\mathrm{pH}: 6.3 \pm 0.34$; oxygen: $188.65 \% \pm 23.41$; and temperature: $23.5^{\circ} \mathrm{C} \pm 1.22($ mean \pm SD), and were not significantly different between transport times ( $P>0.1$ all parameters). Ammonia and nitrate remained at safe levels (i.e. total ammonia nitrogen $<0.93 \mathrm{ppm}$, unionised ammonia $<0.004 \mathrm{ppm}$, nitrate $<21.2 \mathrm{ppm}$ ) during transport and recovery.

During recovery, fish behaviour was recorded once every 7 days for 4 weeks at random times of the day, but not within $1 \mathrm{~h}$ of feeding. The duration of recordings and the camera set up were the same as on arrival. Videos were subsequently used to analyse fish behaviour (Table 1) using Behavioural Observation Research Interactive Software (BORIS) (Friard and Gamba, 2016). Randomly selected focal fish were tracked for 3 min, repeated consecutively from the start to the end of the video such that 10 individuals were tracked. Behaviours for each focal fish were then added to obtain a bag score. Due to the nature of the enrichment analysing the videos blind was not possible as the enrichment was visible in the videos recorded on arrival. Therefore, a subsample ( $\sim 10 \%)$ of videos were analysed blind by an additional observer (inter-observer reliability: Kendall's W coefficient: 0.99). From the videos, any visible body and fin injuries were recorded for focal fish and given a severity score from $0-3$ where $0=$ no injuries and $3=$ major injury (Vanderzwalmen et al. 2019). Scores for fin and body injuries were summed to obtain a total injury score recorded for each 
123 fish which were then summed to obtain a total injury score per bag. This score was then

124 adjusted for the number of fish that remained at each data collection point to account for fish

125 that had been sold or died. From arrival of the fish until the end of the 4-week recovery

126 period, mortality and occurrence of disease was recorded daily by the retail store staff. All

127 fish were fed a commercial diet ad libitum twice daily and kept on a $12 \mathrm{~h}$ light/dark regime.

128 Preliminary trials found that water parameters in the tanks at the stores were $\mathrm{pH}: 6.96 \pm 0.51$;

129 oxygen: $101 \% \pm 1.93$; temperature: $22.42^{\circ} \mathrm{C} \pm 1.6($ mean $\pm \mathrm{SD})$, and were not significantly

130 different between stores ( $\mathrm{p}>0.1$ all parameters). 
131 Table 1. Ethogram of the behaviours recorded.

\begin{tabular}{|c|c|c|}
\hline Behaviour & Description & Relation to welfare \\
\hline Biting & $\begin{array}{l}\text { Fish biting or nipping } \\
\text { a conspecific. }\end{array}$ & $\begin{array}{l}\text { Biting can cause injuries and may lead to mortality } \\
\text { (Pitcher, 1986; Noble et al. 2012). }\end{array}$ \\
\hline Chases & $\begin{array}{l}\text { Occurrence of a fish } \\
\text { chasing a conspecific. }\end{array}$ & $\begin{array}{l}\text { Aggressive interaction has been associated with elevated } \\
\text { stress (Vera Cruz and Brown, 2007; Kadry and Barreto, } \\
\text { 2010; Gronquist and Berges, 2013). }\end{array}$ \\
\hline $\begin{array}{l}\text { Erratic } \\
\text { swimming }\end{array}$ & $\begin{array}{l}\text { Occurrence of rapid } \\
\text { swimming and } \\
\text { direction change in } \\
\text { the absence of being } \\
\text { chased. }\end{array}$ & $\begin{array}{l}\text { Erratic swimming is an indicator of elevated stress, } \\
\text { distress or pathogenic condition and may be used as a } \\
\text { sign of poor welfare (Conte, 2004). }\end{array}$ \\
\hline $\begin{array}{l}\text { Ventilation } \\
\text { rate }\end{array}$ & $\begin{array}{l}\text { Frequency per minute } \\
\text { (Alvarenga and } \\
\text { Volpato, 1995). }\end{array}$ & $\begin{array}{l}\text { Ventilation rate can increase as a result of stressors and } \\
\text { is a highly sensitive mechanism involved in stress } \\
\text { coping strategies (Barreto and Volpato, 2004; Martins et } \\
\text { al. 2012). }\end{array}$ \\
\hline
\end{tabular}




\subsection{Statistical analysis}

134 R 3.6.1 was used for statistical analyses (Bolker et al. 2009; R Core Team, 2019). One outlier from the bite data was removed as it was 22.5 SD away from the mean (Miller, 1991). General linear mixed models (GLMM) were carried out on ventilation rate using the lme function from the lme4 package (Bates et al. 2015). Treatment, recovery stage and transport duration were set as explanatory variables; strain had no significant effect on behaviour and was included as a random variable, as was pair number. Number of fish per bag was five in all cases except in one pair where 10 fish per bag were ordered that week. Therefore, number of fish was not included as a random variable due to the low variation causing singularity when included in models. The interactions between the explanatory variables were also analysed. The distribution of residuals was determined visually (R Core Team, 2019). For response variables recorded as counts, a generalised linear mixed model (GLMM) using poisson family from the lme 4 package was used with the same variables as above (Bates et al. 2015). As necessary, data were log or square root transformed to obtain normally distributed residuals. Percentage data were expressed as proportions and a binomial GLMM was carried out with the fixed and random variables as described above. The best fit model was selected by disregarding explanatory variables that did not significantly improve the fit of the model (Bates et al. 2015). The significance of the explanatory variables was tested using ANOVA at $P<0.05$ (Fox and Weisberg, 2011; Pinheiro et al. 2018) and pair-wise posthoc Tukey tests were carried out (Lenth, 2017). Figures were created using ggplot2 (Wickham et al. 2016). 


\section{Results}

158 Erratic swimming was significantly affected by treatment, recovery stage and

159 transport duration (Table 2). Erratic swimming was consistently lower in fish transported

160 with enrichment than controls (Fig. 2). In fish that experienced the short transport, erratic

161 swimming decreased during week 1 of recovery but then rose within the following weeks to

162 similar levels seen on arrival (Fig. 2). In fish from the long transport, however, erratic

163 swimming was lower during recovery than on arrival and remained low throughout recovery

164 (Fig. 2).

165 Table 2 ANOVA result of best fit model for erratic swimming and chasing with $F$ values, 166 degrees of freedom (df), and $P$ values. Significant p-values are indicated in bold.

\begin{tabular}{llrrrr}
\hline Behaviour & Fixed Effect & numDF & denDF & $F$-value & $P$ \\
& & & & & \\
\hline Erratic & Treatment & 1 & 78 & 125.8 & $<\mathbf{0 . 0 0 0 1}$ \\
& & & & & \\
& Recovery Stage & 4 & 78 & 108.31 & $<\mathbf{0 . 0 0 0 1}$ \\
& Transport Duration & 1 & 9 & 36.92 & $<\mathbf{0 . 0 0 0 1}$ \\
& Treatment * Recovery Stage & 4 & 78 & 2.413 & 0.075 \\
& Recovery Stage * Transport & 4 & 78 & 48.062 & $<\mathbf{0 . 0 0 0 1}$ \\
& Duration & & & & \\
& Treatment * Transport Duration & 1 & 78 & 0.391 & 0.563 \\
& Treatment * Recovery Stage * & 4 & 78 & 2.404 & $\mathbf{0 . 0 4 6}$ \\
& Transport Duration & & & & \\
& Treatment & & & & \\
& Recovery Stage & 1 & 88 & 173.614 & $<\mathbf{0 . 0 0 0 1}$ \\
& Transport Duration & 4 & 88 & 35.09 & $<\mathbf{0 . 0 0 0 1}$ \\
& Treatment * Recovery Stage & 1 & 5 & 0.008 & 0.842 \\
& Treatment * Transport Duration & 1 & 95 & 0.196 & 0.669
\end{tabular}




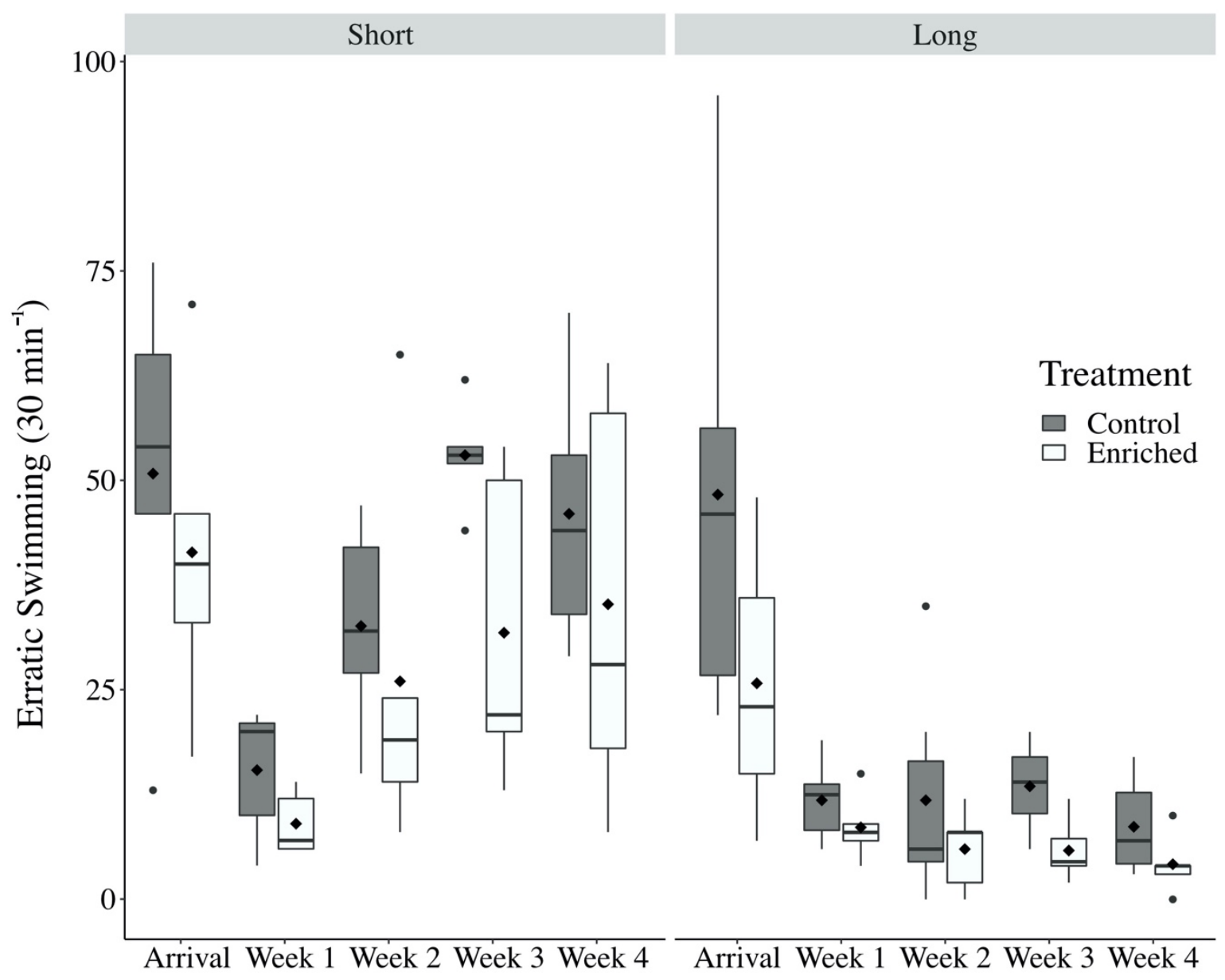

169 Figure 2: Occurrence of erratic swimming in fish transported with or without environmental

170 enrichment for a short and long transport. Data are mean (diamond), median, upper and lower

171 25th percentile, and outliers, $n=5$ bags per treatment for short and $n=6$ for long transport.

172 Asterisks indicate a significant difference between treatments within a time point (post- hoc

173 Tukey, $P<0.05)$. Lowercase letters indicate significance between stage of transport within

174 control (a-f) and enriched ( $\mathrm{v}-\mathrm{z}$ ) treatments, with separate post-hoc analyses used for short and

175 long transport duration. Boxes sharing a letter are not significantly different (post-hoc Tukey, $176 P<0.05)$. 
177 Chasing was significantly affected by treatment and recovery stage with a significant

178 interaction between the two factors (Table 2). However, unlike for erratic swimming, there

179 was no effect of transport duration on chasing. Chasing behaviour was low on arrival at the

180 stores for both treatments but increased during the recovery period, remaining lower in the

181 fish transported with enrichment (Fig. 3). In fish from the control treatment, chasing was

182 significantly higher than on arrival by week 1 of recovery and remained high, while the

183 number of chases in the enriched treatment only began to increase slowly from week 3 of

184 recovery (Fig. 3). Biting behaviour, injury score, mortality and ventilation rate were not

185 significantly affected by treatment, recovery stage or duration $(P>0.05$ for all, Table $\mathrm{S} 1$

186 supplementary material) and remained low throughout (Table S2 supplementary material).

187 Occurrence of disease was too low to carry out statistical analyses. 
191 Figure 3: Occurrence of chasing in fish transported with or without environmental

192 enrichment. Data are mean (diamond), median, upper and lower 25th percentile, and outliers,

$193 \mathrm{n}=11$. Asterisks indicate a significant difference between treatments within a specific time

194 point (post-hoc Tukey, $P<0.05$ ). Letters indicate a significant difference between stages of 195 transport within control $(\mathrm{a}-\mathrm{c})$ and enriched $(\mathrm{x}, \mathrm{y})$ treatments where boxes sharing a letter are 196 not significantly different (post-hoc Tukey, $P<0.05$ ). 


\section{Discussion}

198 Fish that were transported with enrichment showed a reduction in stress-associated

199 behaviours including erratic swimming and chasing. Erratic swimming in the enriched group

was lower on arrival at stores than in the control group, and during recovery fish shipped with enrichment showed lower levels of chasing.

Some chasing and biting are expected during hierarchy establishment, but prolonged chasing can lead to chronic stress for the fish subjected to the aggressive behaviour (Braddock, 1945; Scott and Currie, 1980). Following stress, fish can display displaced aggression behaviours, such as chasing, as a coping mechanism to manage their own stress (Sneddon et al., 2016). Reduced aggression could therefore indicate improved stress-coping capabilities in the enriched group (Sneddon et al., 2016). Lower levels of chasing in the enriched group may also suggest a less aggressive establishment of hierarchy. Biting behaviours are a greater welfare concern than chasing due to risks of injury and infection but were low throughout the present study. 
can experience stress for extended periods of time following transport (Knowles et al. 1993;

222 Dembiec et al. 2004; Fernström et al. 2008), in the present study indicators of stress were

223 recorded for four weeks post-transport. While differences in behaviour between treatments

224 were seen over this time frame, mortality, disease and injury were not affected by enrichment 225 most likely as levels of all three remained low throughout the study.

226

227

228

229

230

\section{1}

al. 2016) and a similar result was seen in jundiá (Rhamdia quelen) (Barcellos et al. 2009).

234 Exposure to blue subtrate prior, during and after a confinement stress also improved the recovery rate of serotonin and plasma glucose in gilthead seabream (Sparus aurata) (Batzina ornamental trade to reduce the stress experienced by some species, meaning it is an enrichment which reflects current practice and could be implemented for other species. Prior

244 to the present study, there had been no research on the use of plastic loops as enrichment 
245 during ornamental fish transport. Plastic loops are likely to disturb visual contact between

246 fishes within the transport bag and might provide hiding places, however, further research is

247 needed to better understand the functionality of the plastic loops as enrichment. More

248 research is also needed to identify other potential forms of enrichment during ornamental fish

249 transport across different species and life-stages. Consideration must be given to the fact that

250 the type of environmental enrichment provided is likely to affect both the response of the

\section{Conclusion}

261 Millions of animals are transported daily across the world. Transport is stressful for these animals, yet surprisingly few studies have assessed the effect of enrichment during animal transport. This study is the first to use enrichment during the commercial transport of

264 ornamental fishes, finding a clear benefit in the reduction of stress-associated behaviours.

265 With growing pressure on industries to improve the welfare of the animals they care for, 266 further research into environmental enrichment to manage stress during commercial transport 267 is warranted. 
Acknowledgments

Many thanks to management and staff at the wholesaler and retail stores where data

271 were collected.

272

\section{3}

274

275

\section{References}

Acerete, L., Balasch, J.C., Espinosa, E., Josa, A., Tort, L., 2004. Physiological responses in Eurasian perch (Perca fluviatilis, L.) subjected to stress by transport and handling. Aquaculture 237, 167-178. https://doi:10.1016/j.aquaculture.2004.03.018

Alvarenga, C.M.D., Volpato, G.L., 1995. Agonistic profile and metabolism in alevins of the Nile Tilapia. Physiol. Behav. 57, 75-80. https://doi.org/10.1016/0031-9384(94)00206-K

Barcellos, L.J.G., Kreutz, L.C., Quevedo, R.M., da Rosa, J.G.S., Koakoski, G., Centenaro, L., Pottker, E., 2009. Influence of color background and shelter availability on jundiá (Rhamdia quelen) stress response. Aquaculture 288, 51-56.

\section{https://doi.org/10.1016/j.aquaculture.2008.11.002}

Barreto, R.E., Volpato, G.L., 2004. Caution for using ventilatory frequency as an indicator of stress in fish. Behav. Processes 66, 43-51. https://doi.org/10.1016/j.beproc.2004.01.001 
291 Baumans, V., 2005. Environmental enrichment for laboratory rodents and rabbits:

292 Requirements of rodents, rabbits, and research. ILAR J. 46, 162-170.

293 https://doi.org/10.1093/ilar.46.2.162

294 Belz, E.E., Kennell, J.S., Czambel, R.K., Rubin, R.T., Rhodes, M.E., 2003. Environmental

295 enrichment lowers stress-responsive hormones in singly housed male and female rats.

296 Pharmacol. Biochem. Behav. 76, 481-486. https://doi.org/10.1016/j.pbb.2003.09.005

297 Bloomsmith, M.A., Lambeth, S.P., 2000. Videotapes as enrichment for captive chimpanzees 298 (Pan troglodytes). Zoo Biol. 19, 541-551.

299 Bolker, B.M., Brooks, M.E., Clark, C.J., Geange, S.W., Poulsen, J.R., Stevens, M.H.H., 300 White, J.S.S., 2009. Generalized linear mixed models: a practical guide for ecology and 301 evolution. Trends Ecol. Evol. 24, 127-135. https://doi.org/10.1016/j.tree.2008.10.008

302 Bono, L., Mongillo, P., De Boni-Russo, G., Gabai, G., Normando, S., 2016. Effects of two 303 forms of environmental enrichment on a group of captive blackbucks (Antilope cervicapra):

304 A pilot study. J. Vet. Behav. Clin. Appl. Res. 12, 66-72.

305 https://doi:10.1016/j.jveb.2016.02.003

306 Braddock, J.C., 1945. Some aspects of the dominance-subordination relationship in the fish

307 Platypoecilus maculatus. Physiol. Zool. 18, 176-195.

308 https://doi:10.1086/physzool.18.2.30151863

309 Carlstead, K., Shepherdson, D., 2000. Alleviating stress in zoo animals with environmental 310 enrichment, in: Moberg, G.P., Mench, J.. (Eds.), The Biology of Animal Stress: Basic

311 Principles and Implications for Animal Welfare. CABI publishing, Oxford, UK, pp. 337-354.

312 Conte, F., 2004. Stress and the welfare of cultured fish. Appl. Anim. Behav. Sci. 86, 205-

313 223. https://doi.org/10.1016/j.applanim.2004.02.003 
314 Cornale, P., Macchi, E., Miretti, S., Renna, M., Lussiana, C., Perona, G., Mimosi, A., 2015.

315 Effects of stocking density and environmental enrichment on behavior and fecal

316 corticosteroid levels of pigs under commercial farm conditions. J. Vet. Behav. Clin. Appl.

317 Res. 10, 569-576. https://doi.org/10.1016/j.jveb.2015.05.002

318 Costa, R., Sousa, C., Llorente, M., 2018. Assessment of environmental enrichment for

319 different primate species under low budget: A case study. J. Appl. Anim. Welf. Sci. 21, 185-

320 199. https://doi.org/10.1080/10888705.2017.1414606

321 De Rouck, M., Kitchener, A.C., Law, G., Nelissen, M., 2005. A comparative study of the 322 influence of social housing conditions on the behaviour of captive tigers (Panthera tigris). 323 Univ. Fed. Anim. Welf. 14, 229-238.

324 Dembiec, D.P., Snider, R.J., Zanella, A.J., 2004. The effects of transport stress on tiger 325 physiology and behavior. Zoo Biol. 23, 335-346. https://doi.org/10.1002/zoo.20012

326 DeVries, T.J., Vankova, M., Veira, D.M., von Keyserlingk, M.A.G., 2007. Short

327 communication: Usage of mechanical brushes by lactating dairy cows. J. Dairy Sci. 90, 328 2241-2245. https://doi.org/10.3168/jds.2006-648

329 Ellis, S., 2009. Environmental enrichment: practical strategies for improving feline welfare. 330 J. Feline Med. Surg. 11, 901-912.

331 Fernström, A.L., Sutian, W., Royo, F., Westlund, K., Nilsson, T., Carlsson, H.E., Paramastri, 332 Y., Pamungkas, J., Sajuthi, D., Schapiro, S.J., Hau, J., 2008. Stress in cynomolgus monkeys 333 (Macaca fascicularis) subjected to long-distance transport and simulated transport housing 334 conditions. Stress 11, 467-476. https://doi.org/10.1080/10253890801903359

335 Fox, J., Weisberg, S., 2011. An R Companion to Applied Regression, second. ed. Sage, 336 Thousand Oaks, CA. 
337 Friard, O., Gamba, M., 2016. BORIS: a free, versatile open-source event-logging software for 338 video/audio coding and live observations. Methods Ecol. Evol. 7, 1325-1330.

https://doi.org/10.1111/2041-210X.12584

340 Giacomini, A.C.V.V., Abreu, M.S., Zanandrea, R., Saibt, N., Friedrich, M.T., Koakoski, G., 341 Gusso, D., Piato, A.L., Barcellos, L.J.G., 2016. Environmental and pharmacological manipulations blunt the stress response of zebrafish in a similar manner. Sci. Rep. 6, 1-6.

https://doi.org/10.1038/srep28986

344 Grandin, T., 1997. Assessment of stress during handling and transport. J. Anim. Sci. 75, 249345257.

346 Grimberg-Henrici, C.G.E., Vermaak, P., Bolhuis, E.J., Nordquist, R.E., van der Staay, F.J., 347 2016. Effects of environmental enrichment on cognitive performance of pigs in a spatial 348 holeboard discrimination task. Anim. Cogn. 19, 271-283. https://doi.org/10.1007/s10071$349 \quad \underline{015-0932-7}$

350 Gronquist, D., Berges, J.A., 2013. Effects of aquarium-related stressors on the zebrafish: A 351 comparison of behavioral, physiological, and biochemical indicators. J. Aquat. Anim. Health 352 25, 53-65. https://doi.org/10.1080/08997659.2012.747450

353 Harmon, T.S., 2009. Methods for reducing stressors and maintaining water quality associated 354 with live fish transport in tanks: a review of the basics. Rev. Aquac. 1, 58-66.

355 https://doi.org/10.1111/j.1753-5131.2008.01003.x

356 Ingrum, J., Nordell, S.E., Dole, J., 2010. Effects of habitat complexity and group size on 357 perceived predation risk in goldfish (Carassius auratus). Ethol. Ecol. Evol. 22, 119-132. 358 https://10.1080/03949371003707638

359 Kadry, V.O., Barreto, R.E., 2010. Environmental enrichment reduces aggression of pearl 
360 cichlid, Geophagus brasiliensis, during resident-intruder interactions Vivian. Neotrop.

361 Ichthyol. 8, 329-332. https://doi.org/10.1590/S1679-62252010000200011

362 Knowles, T.G., Warriss, P.D., Brown, S.N., Kestin, S.C., Rhind, S.M., Edwards, J.E., Anil,

363 M.H., Dolan, S.K., 1993. Long distance transport of lambs and the time needed for

364 subsequent recovery. Vet. Rec. 133, 283-286.

365 Lenth, R. V, 2017. Least-squares means: The R package lsmeans. J. Stat. Softw. 69, 1-33.

366 https://doi.org/10.18637/jss.v069.i01

367 Martins, C.I.M., Galhardo, L., Noble, C., Damsgård, B., Spedicato, M.T., Zupa, W.,

368 Beauchaud, M., Kulczykowska, E., Massabuau, J.-C., Carter, T., Planellas, S.R., Kristiansen,

369 T., 2012. Behavioural indicators of welfare in farmed fish. Fish Physiol. Biochem. 38, 17-41.

370 https://doi.org/10.1007/s10695-011-9518-8

371 Mileva, G.R., Bielajew, C., 2015. Environmental manipulation affects depressive-like

372 behaviours in female Wistar-Kyoto rats. Behav. Brain Res. 293, 208-216.

https://doi.org/10.1016/j.bbr.2015.07.035

374 Milgram, N.W., Head, E., Zicker, S.C., Ikeda-Douglas, C.J., Murphey, H., Muggenburg, B., 375 Siwak, C., Tapp, D., Cotman, C.W., 2005. Learning ability in aged beagle dogs is preserved 376 by behavioral enrichment and dietary fortification: A two-year longitudinal study. Neurobiol.

377 Aging 26, 77-90. https://doi.org/10.1016/j.neurobiolaging.2004.02.014

378 Miller, J., 1991. Short report: reaction time analysis with outlier exclusion: bias varies with 379 sample size. Q. J. Exp. Psychol. 43, 907-912. https://10.1080/14640749108400962

380 Millidine, K.J., Armstrong, J.D., Metcalfe, N.B., 2006. Presence of shelter reduces

381 maintenance metabolism of juvenile salmon. Funct. Ecol. 20, 839-845.

382 https://doi.org/10.1111/j.1365-2435.2006.01166.x 
383 Näslund, J., Johnsson, J.I., 2016. Environmental enrichment for fish in captive environments:

384 Effects of physical structures and substrates. Fish Fish. 17, 1-30.

385 https://doi.org/10.1111/faf.12088

386 Noble, C., Jones, H.A.C., Damsgård, B., Flood, M.J., Midling, K.O., Roque, A., Sæther, B.S. 387 Cottee, S.Y., 2012. Injuries and deformities in fish: Their potential impacts upon aquacultural 388 production and welfare. Fish Physiol. Biochem. 38, 61-83. https://doi.org/10.1007/s10695-

\section{$389 \quad \underline{011-9557-1}$}

390 Nomura , M., Sloman, K.A., von Keyserlingk, M.A.G., Farrell, A.P., 2009. Physiology and 391 behaviour of Atlantic salmon (Salmo salar) smolts during commercial land and sea transport. 392 Physiol. Behav. 96, 233-243. https://doi:10.1016/j.physbeh.2008.10.006

393 Pattanasiri, T., Taparhudee, W., Suppakul, P., 2017. Anaesthetic efficacy of clove oil-coated

394 LDPE bag on improving water quality and survival in the Siamese fighting fish, Betta

395 splendens, during transportation. Aquac. Int. 25, 197-209. https://doi.org/10.1007/s10499-

$396 \quad \underline{016-0020-2}$

397 Peeters, E., Geers, R., 2006. Influence of provision of toys during transport and lairage on

398 stress responses and meat quality of pigs. Anim. Sci. 82, 591-595.

399 https://doi.org/10.1079/asc200686

400 Pickering, A., Pottinger, T., Christie, P., 1982. Recovery of the brown trout, Salmo trutta L., 401 from acute handling stress: a time course study. J. Fish Biol. 20, 229-244.

402 Pinheiro, J., Bates, D., DebRoy, S., Sarkar, D., R Core Team, 2018. nlme: Linear and 403 Nonlinear Mixed Effects Models. https://cran.r-project.org/web/packages/nlme/index.html

404 Pitcher, T.J. (Ed.), 1986. The Behaviour of Teleost Fishes, Springer Science \& Business 405 Media. Croom Helm, London, UK. https://doi.org/10.1007/978-1-4684-8261-4_5 
406 R Core Team, 2019. R: A Language and Environment for Statistical Computing.

407 Ramírez-duarte, W.F., Pineda-quiroga, C., Rueda, N.M., 2013. Evaluation of the use of 408 sodium chloride, eugenol, and zeolite in confinement of Ancistrus triradiatus. Orinoquia 17, $40984-95$.

410 Roldan-Santiago, P., Trujillo-Ortega, M., Borderas-Tordesillas, F., Martínez-Rodríguez, R.,

411 Mora-Medina, P., Flores-Peinado, S., Sánchez-Hernández, M., García-Herrera, R., González-

412 Lozano, M., Mota-Rojas, D., 2015. Physiometabolic responses to road transport in weaned

413 piglets for a short period and the effects of straw bedding. Anim. Sci. J. 86, 563-571.

414 https://doi.org/10.1111/asj.12324

415 Rozek, J.C., Millam, J.R., 2011. Preference and motivation for different diet forms and their 416 effect on motivation for a foraging enrichment in captive orange-winged Amazon parrots 417 (Amazona amazonica). Appl. Anim. Behav. Sci. 129, 153-161.

$418 \quad$ https://doi.org/10.1016/j.applanim.2010.11.009

419 Salaro, A.L., Camplelo, D.A.V., Tavares, M.M., Braga, L.G.T., Pontes, M.D., Zuanon, 420 J.A.S., 2015. Transport of Astyanax altiparanae Garutti and Britski, 2000 in saline water. 421 Acta Sci. - Biol. Sci. 37, 137-142. https://doi.org/10.4025/actascibiolsci.v37i2.26884

422 Scott D.B.C., Currie C.E. 1980 Social hierarchy in relation to adrenocortical activity in 423 Xiphophorus helleri Heckel. J. Fish Biol. 16, 265-277. https://doi:10.1111/j.1095-

\section{$424 \quad$ 8649.1980.tb03704.x}

425 Skibiel, A.L., Trevino, H.S., Naugher, K., 2007. Comparison of several types of enrichment 426 for captive felids. Zoo Biol. 26, 371-381. https://doi.org/10.1002/zoo

427 Sloman, K.A., Baldwin, L., McMahon, S., Snellgrove, D., 2011. The effects of mixed-species 428 assemblage on the behaviour and welfare of fish held in home aquaria. Appl. Anim. Behav. 
430 Sneddon, L.U., Wolfenden, D.C.C., Thomson, J.S., 2016. Stress management and welfare, in:

431 Schreck, C.B., Tort, L., Farrell, A.P., Brauner, C.J. (Eds.), Biology of Stress in Fish: Fish

432 Physiology. Elsevier Inc., London, UK, pp. 463-539. https://doi.org/10.1016/B978-0-12-

\section{$433 \quad \underline{802728-8.00012-6}$}

434 Sullivan,M., Lawrence, C., Blache, D., 2016. Why did the fish cross the tank? Objectively 435 measuring the value of enrichment for captive fish. Appl. Anim. Behav. Sci. 174, 181-188.

436 https://doi:10.1016/j.applanim.2015.10.011

437 Ullah, I., Zuberi, A., Khan, K.U., Ahmad, S., Thörnqvist, P.O., Winberg, S., 2017. Effects of 438 enrichment on the development of behaviour in an endangered fish mahseer (Tor putitora). 439 Appl. Anim. Behav. Sci. 186, 93-100. https://doi.org/10.1016/j.applanim.2016.10.016

440 Vanderzwalmen, M., Edmonds, E., Carey, P., Snellgrove, D., Sloman, K. A., 2019. Effect of 441 a water conditioner on ornamental fish behaviour during commercial transport. Aquaculture 442514,734486

443 Vera Cruz, E.M., Brown, C.L., 2007. The influence of social status on the rate of growth, eye 444 color pattern and Insulin-like Growth Factor-I gene expression in Nile tilapia, Oreochromis 445 niloticus. Horm. Behav. 51, 611-619. https://doi.org/10.1016/j.yhbeh.2007.02.010

446 Wickham, H., 2016. ggplot2: Elegant Graphics for Data Analysis. Springer-Verlag New 447 York.

448 Wilson, S.C., Mitlöhner, F.M., Morrow-Tesch, J., Dailey, J.W., McGlone, J.J., 2002. An 449 assessment of several potential enrichment devices for feedlot cattle. Appl. Anim. Behav. Sci. 450 76, 259-265. https://doi:10.1016/S0168-1591(02)00019-9

451 Wood, W., 1998. Interactions among environmental enrichment, viewing crowds, and zoo 
452 chimpanzees (Pan troglodytes). Zoo Biol. 17, 211-230. https://doi.org/10.1002/(SICI)1098-

\section{$453 \quad 2361(1998) 17: 3<211::$ AID-ZOO5 $>3.0 . C O ; 2-C$}

454 Young, R.J., 2003. Environmental Enrichment for Captive Animals, 1st ed. Blackwell

455 Science Ltd, Oxford, UK.

456 Zanuzzo, F.S., Biller-Takahashi, J.D., Urbinati, E.C., 2012. Effect of Aloe vera extract on the 457 improvement of the respiratory activity of leukocytes of matrinxã during the transport stress.

458 Rev. Bras. Zootec. 41, 2299-2302. https://doi.org/10.1590/S1516-35982012001000023 


\section{End Section Statements}

\section{Competing Interests}

462 The authors declare no competing interests.

\section{$463 \quad$ Funding}

464 The work was part-funded by Waltham Petcare Science Institute (Mars Petcare) and the 465 University of the West of Scotland. 


\section{Declaration of interests}

૫ The authors declare that they have no known competing financial interests or personal relationships that could have appeared to influence the work reported in this paper.

$\square$ The authors declare the following financial interests/personal relationships which may be considered as potential competing interests:

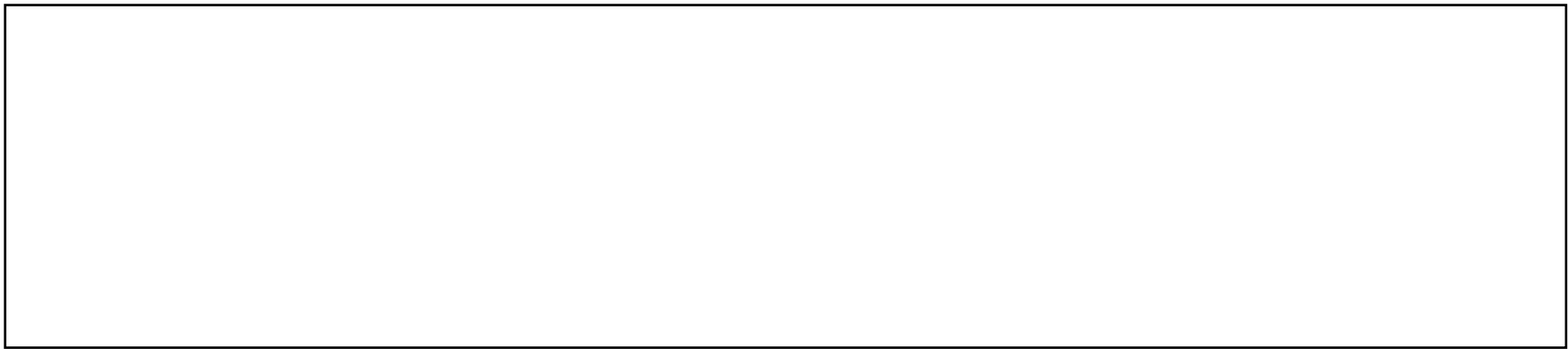


Myriam Vanderzwalmen: Conceptualization, Methodology, Formal analysis, Investigation, Writing - Original Draft

Peter Carey: Conceptualization, Resources, Writing - Review \& Editing

Donna Snellgrove: Conceptualization, Writing - Review \& Editing

Katherine Sloman: Conceptualization, Methodology, Writing - Review \& Editing, Supervision 


\section{Supplementary Material}

2 Table S1 ANOVA result of best fit model for biting, injury score, mortality and ventilation rate with $F$ values, degrees of freedom (df), and $P$ values.

\section{Fixed Effect} numDF denDF $F$-value

$P$

\begin{tabular}{llrrrr}
\hline Biting & Treatment & 1 & 91 & 3.634 & 0.55 \\
& Recovery Stage & 4 & 91 & 0.366 & 0.83 \\
& Transport Duration & 1 & 9 & 0.098 & 0.75 \\
Injury score & Treatment & 1 & 72 & 0.044 & 0.833 \\
& Recovery Stage & 4 & 72 & 0.271 & 0.846 \\
& Transport Duration & 1 & 5 & 2.225 & 0.195 \\
Mortality & Treatment & 1 & 94 & 2.434 & 0.122 \\
& Recovery Stage & 4 & 94 & 0.764 & 0.551 \\
& Transport Duration & 1 & 5 & 0.054 & 0.825 \\
Ventilation Rate & Treatment & 1 & 92 & 0.003 & 0.955 \\
& Recovery Stage & 4 & 92 & 2.16 & 0.079 \\
& Transport Duration & 1 & 4 & 0.215 & 0.661 \\
\hline
\end{tabular}




\begin{tabular}{|c|c|c|c|c|c|}
\hline Stage & Treatment & $\begin{array}{l}\text { Transport } \\
\text { duration }\end{array}$ & $\begin{array}{l}\text { Biting } \\
\left(30 \mathrm{~min}^{-1}\right)\end{array}$ & $\begin{array}{l}\text { Ventilation rate } \\
\min ^{-1}\end{array}$ & $\begin{array}{l}\text { Injury score } \\
\text { (average per } \\
\text { fish, see text) }\end{array}$ \\
\hline Arrival & Control & Short & $0( \pm 0)$ & $105.05( \pm 9.11)$ & $0( \pm 0)$ \\
\hline Arrival & Enriched & Short & $0( \pm 0)$ & $99.70( \pm 4.71)$ & $0( \pm 0)$ \\
\hline Arrival & Control & Long & $2.6( \pm 5.81)$ & $106.80( \pm 10.20)$ & $0.04( \pm 0.09)$ \\
\hline Arrival & Enriched & Long & $0( \pm 0)$ & $116.49( \pm 28.45)$ & $0.08( \pm 0.18)$ \\
\hline Week 1 & Control & Short & $0( \pm 0)$ & $105.74( \pm 5.71)$ & $0( \pm 0)$ \\
\hline Week 1 & Enriched & Short & $0.80( \pm 1.30)$ & $98.66( \pm 7.79)$ & $0.08( \pm 0.18)$ \\
\hline Week 1 & Control & Long & $0.4( \pm 0.89)$ & $102.27( \pm 12.75)$ & $0.267( \pm 0.60)$ \\
\hline Week 1 & Enriched & Long & $0( \pm 0)$ & $106.41( \pm 13.81)$ & $0.32( \pm 0.46)$ \\
\hline Week 2 & Control & Short & $0.4( \pm 0.89)$ & $107.54( \pm 14.60)$ & $0.08( \pm 0.18)$ \\
\hline Week 2 & Enriched & Short & $0( \pm 0)$ & $110.57( \pm 13.93)$ & $0.2( \pm 0.45)$ \\
\hline Week 2 & Control & Long & $0.5( \pm 0.55)$ & $106.04( \pm 13.62)$ & $0.07( \pm 0.10)$ \\
\hline Week 2 & Enriched & Long & $0.17( \pm 0.41)$ & $105.49( \pm 13.23)$ & $0.8( \pm 0.167)$ \\
\hline Week 3 & Control & Short & $0.2( \pm 0.45)$ & $111.89( \pm 8.05)$ & $0.28( \pm 0.39)$ \\
\hline Week 3 & Enriched & Short & $0( \pm 0)$ & $106.19( \pm 7.88)$ & $0.04( \pm 0.09)$ \\
\hline Week 3 & Control & Long & $0.33( \pm 0.82)$ & $112.83( \pm 12.63)$ & $0.12( \pm 0.31)$ \\
\hline Week 3 & Enriched & Long & $0( \pm 0)$ & $114.65( \pm 20.74)$ & $0.32( \pm 0.49)$ \\
\hline Week 4 & Control & Short & $0.2( \pm 0.45)$ & $106.73( \pm 10.03)$ & $0( \pm 0)$ \\
\hline Week 4 & Enriched & Short & $0( \pm 0)$ & $103.99( \pm 10.03)$ & $0.1( \pm 0.22)$ \\
\hline Week 4 & Control & Long & $0.5( \pm 0.84)$ & $102.41( \pm 13.44)$ & $0.5( \pm 0.78)$ \\
\hline Week 4 & Enriched & Long & $0( \pm 0)$ & $103.58( \pm 17.01)$ & $0.19( \pm 0.30)$ \\
\hline
\end{tabular}

